\title{
Notes on the Natural History of the Hispaniolan Brown Racer, Haitiophis anomalus (Squamata: Dipsadidae), in the Southern Dominican Republic
}

\author{
Miguel A. Landestoy T. ${ }^{1}$, Robert W. Henderson ${ }^{2}$, Ernst Rupp ${ }^{3}$, Cristian Marte ${ }^{4}$, and Robert A. Ortíz ${ }^{1}$ \\ ${ }^{1}$ Sociedad Ornitológica de la Hispaniola, Santo Domingo, Distrito Nacional, República Dominica (mango_land@yahoo.com) \\ ${ }^{2}$ Milwaukee Public Museum, Milwaukee, Wisconsin 53233, USA \\ ${ }^{3}$ Grupo Jaragua, Santo Domingo, Distrito Nacional, República Dominicana \\ ${ }^{4}$ Museo Nacional de Historia Natural de Santo Domingo, Distrito Nacional, República Dominicana
}

\begin{abstract}
A taxonomic revision based on molecular and morphological data presented a new classification for West Indian racer snakes (Hedges et al. 2009) and the Hispaniolan Brown Racer (Fig. 1), formerly placed in the genus Alsophis, was assigned to the monotypic genus Haitiophis. Haitiophis anomalus is rarely encountered, thus its ecology remains largely unknown (Henderson and Powell 2009). The rarity of this species has been inexplicable (Powell and Henderson 1998), although Hedges and Conn (2012) provided substantial and convincing evidence that the Small Indian Mongoose (Urva auropunctata) has been the major cause of extirpations and extinctions of Caribbean island reptiles. Among dipsadid snakes in the West Indies, its size (maximum SVL of about $2.0 \mathrm{~m}$; Thomas et al. 2007; Fig. 2) is rivaled only by Clelia clelia (which may be extirpated on Grenada). It is certainly the longest dipsadid endemic to the West Indies.

Here, based on many years of experience within the geographic range and habitat of $H$. anomalus, we present observations on various aspects of the natural history of the Hispaniolan Brown Racer.
\end{abstract}

\section{Methods}

Over the past 14 years (with more focused activity from October 2008 and continuing into 2010), the authors and associates have had 31 encounters with Haitiophis anomalus, including both living and dead (e.g., road kills) individuals. These encounters provided the basis for the information presented here. Most of the observations are based on fortuitous observations in the field. However, one of us (MALT) has maintained several individuals of $H$. anomalus in captivity. These animals were kept in an enclosure with a leaf litter substrate and water supply and were fed laboratory mice. Various activities of these captive snakes were recorded with a video camera. We are therefore able to supplement field data with observations of the confined animals.

\section{Distribution and New Localities}

The distribution of Haitiophis anomalus on Hispaniola (Fig. 3) is likely islandwide (including the satellite islands of Île de la Tortue and Isla Beata), but it is nowhere common. Most records for the species are from the southern half of the island, and most of those are from the Dominican Republic. Elevational distribution is from $24 \mathrm{~m}$ below sea level near Las Baitoas (west of Duvergé) and the highest elevation is about $500 \mathrm{~m}$ in the Puerto Escondido valley in the Sierra de Bahoruco near La Placa. A freshly killed female (MNHNSD 23.1013) was found on HW 44 just east of the village of Las Minas (N18.47967, W71.03028) between Azua and Barahona Provinces and is the easternmost locality for the species. Additional specimens have come from the northern shore of Lago Enriquillo near La Descubierta (A. Schubert, pers. comm.) and another near the entrance of Parque Nacional Jaragua (MALT, Rodríguez 2006, Thomas et al. 2007). Three roadkills found in the Valle de Neiba, one in June 1997 (Powell and Henderson 1998), another in June 1999 (R. Powell, pers. comm.), and the third in August 2008 (MALT), represented the most recent records on the main island of Hispaniola until our more intensive efforts. Ducoudray (1981) reported one individual captured alive on Isla Beata and commented on its ecology. Additional sightings were made on the Peninsula de Barahona at Fondo Paradí (live snake, October 2011), Recta de Sansón (two roadkills), and at Loma del Burro (roadkill); all three localities are in or at the boundary of Parque Nacional Jaragua. 


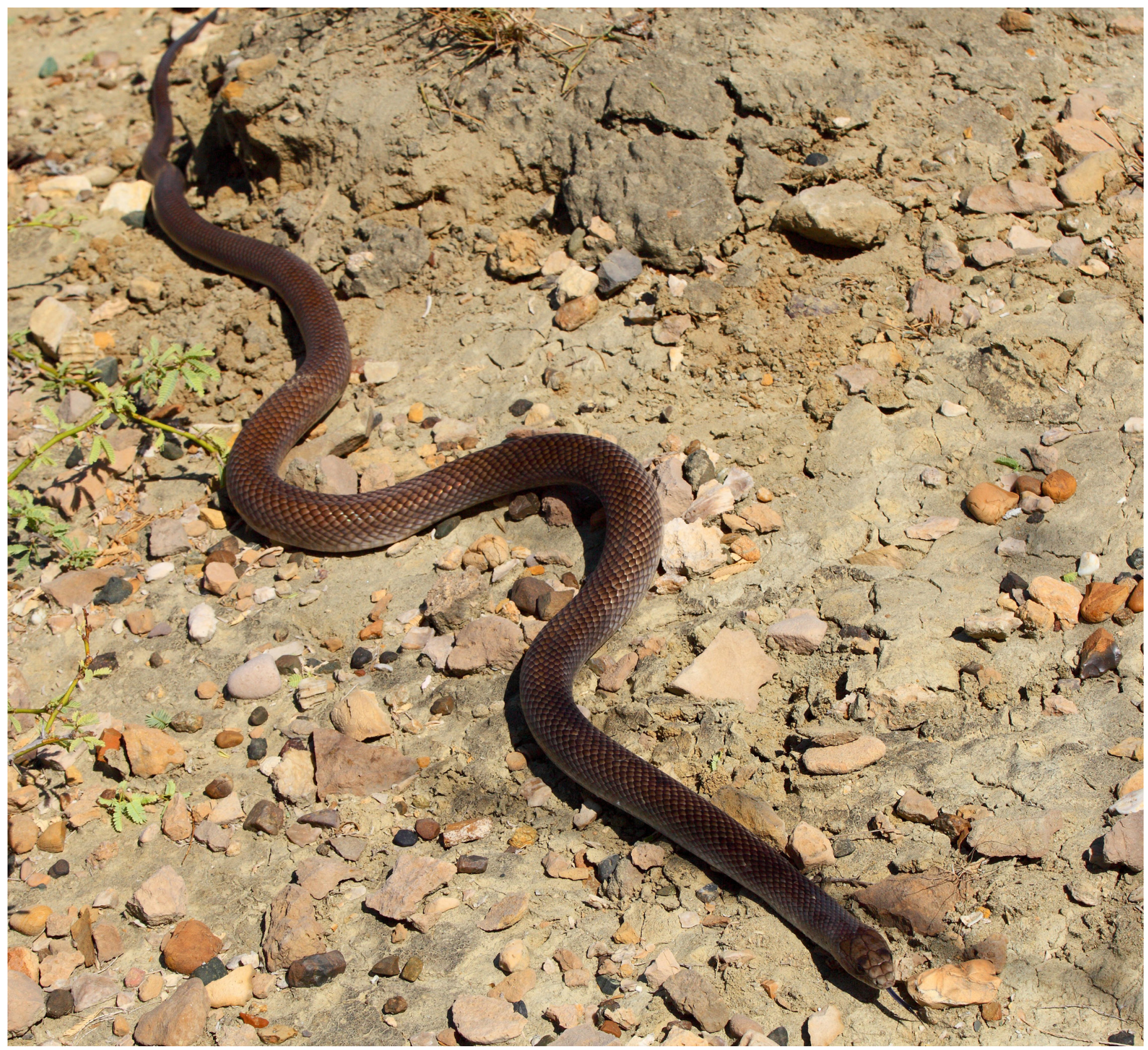

Fig. 1. Adult Hispaniolan Brown Racer (Haitiophis anomalus) captured between Las Baitoas and La Florida (west of Duvergé) on 9 May 2009. Photograph by Miguel A. Landestoy T.

\section{Habitat}

The habitat of $H$. anomalus has been described as open thorny scrub on Isla Beata (Ducoudray 1981, Schwartz and Henderson 1991), which describes most habitat in the Valle de Neiba (Fig. 4). This species has been found at the edges of oases where larger trees along lakeshores west of Las Baitoas and at La Azufrada provided shaded situations. The upper extreme of the elevational distribution is located at La Placa, on the northern slopes of the Sierra de Bahoruco in the Puerto Escondido valley, where three $H$. anomalus were found. That specific area bears a depression that has been defined geomorphologically as the "polje of Fondo del Rejanal" (Martinez Batlle 2012). Locally, the vegetation is considered mesic
(Martinez Batlle 2012) or transitional broadleaf forest. The habitat at the depression is partially covered with relatively larger trees and denser undergrowth (up to $85 \%$ of coverage; Grupo Jaragua 2008) than in the surrounding hills (which become xeric away from the depression) and the dominant tree species is Baitoa (Phyllostylon rhamnoides). In 2004, large portions of the natural habitat were eliminated and the area was developed for avocado farming (Martinez Batlle 2012; Fig. 5). Despite alterations to this landscape, two of the three aforementioned $H$. anomalus were found on the dirt road that divides the farm (N18.34930, W71.60674; $440 \mathrm{~m}$ ). One was alive and the other dead, presumably killed by farm workers. Whether these snakes foraged on the farm or were moving to 


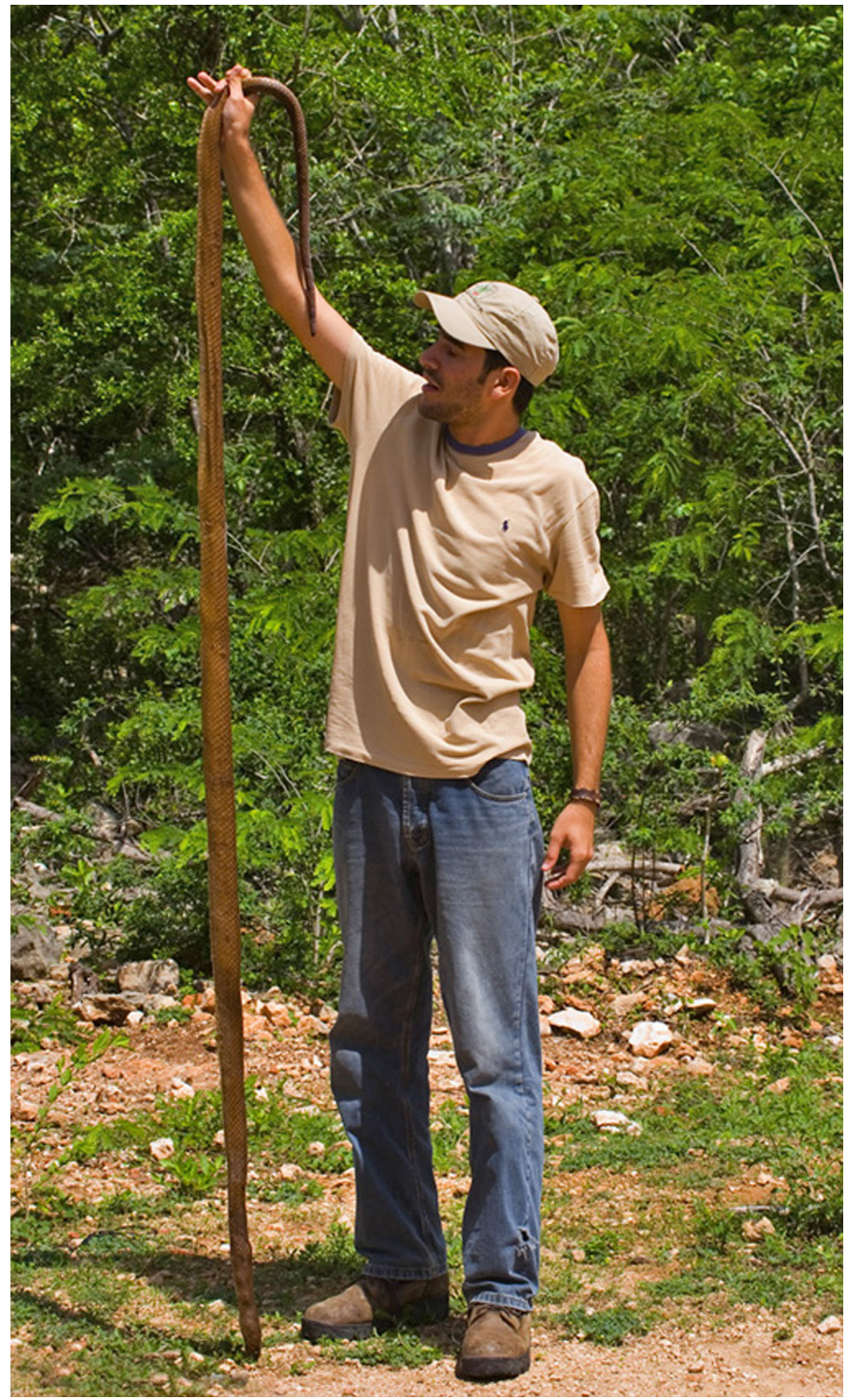

Fig. 2. The senior author holding an adult Hispaniolan Brown Racer (Haitiophis anomalus) of record size $(2,743 \mathrm{~mm}$ TL) found at Fondo Paradí, Parque Nacional Jaragua, Pedernales Province on 24 June 2006. The specimen is deposited in the collection at the University of Puerto Rico-Río Piedras (UPRRP 6492). Photograph by Pedro G. Rodríguez.

the surrounding hill habitat is unknown. Habitat becomes more mesic to both the east and west along the Puerto Escondido valley, increasing in elevation in the latter direction from Rejanal to El Aguacate. Similar habitat conditions are found in the eastern Sierra de Neiba south of Cabeza de Toro, at the western edge of the Parque Nacional Anacaona, where two roadkills were found on the new highway that connects the valleys of Neiba and San Juan. The freshly killed female (MNHNSD 23.1013) found east of Las Minas was in dry hilly country at the southern edge of that same protected area on the xeric northern slopes of the Sierra Martin Garcia (south of Río Yaque del Sur). On three occasions this species has shown arboreal tendencies, once on Île de la
Tortue, where a snake was found in a mango tree (Schwartz and Henderson 1991) and twice in the Dominican Republic, where one sought refuge in a tree when chased by a would-be predator near La Placa and the other was in a bush covered with vines in Fondo Paradí in transitional, well shaded forest in the Parque Nacional Jaragua. Two of three roadkills were found near this park, where the vegetation consists of areas formerly cleared for monocultures (Agave and Aloe) in the Sabana de Sansón, now secondary scrub, and the third was in the xeric karst of Jaragua at Loma del Burro.

Curiously, of 31 encounters with this species, none were with juveniles; all snakes have been in excess of $1.0 \mathrm{~m}$ total length. This could suggest spatial segregation of adults and juveniles, as ophiophagy has been documented for the species (A. Schubert, pers. comm. 2013). Alternatively, juveniles may select different habitats for reasons related to diet or adults simply are more conspicuous because of their size and increased activity related to reproduction.

\section{Activity}

Activity in Haitiophis anomalus is diurnal and most encounters with active individuals in the Valle de Neiba and surrounding areas $(\mathrm{n}=8)$ occurred in the early morning $(0815-$ $0830 \mathrm{~h}$ ) and late afternoon (1540-1700 h), suggesting that snakes avoid extreme daytime temperatures. Those found in the morning were on different days but on the same road. A female (MNHNSD 23.1053) was seen at the side of the road on a bank that faces east at $0815 \mathrm{~h}$. This individual might have been surprised while basking as the sun was already striking the hillside slopes. A male was observed at $0830 \mathrm{~h}$ on the dirt road that connects HW 46 (El Limón-Duvergé) with RD 541 (Puerto Escondido). It was in the middle of the road and, when approached by vehicle, it elevated about one fourth of its body and remained motionless, as if it were observing us and assessing the potential danger. Two other individuals were observed at about $1700 \mathrm{~h}$, also on different days. One was in the middle of HW 46 west of Las Baitoas and the other was nearby in roadside vegetation.

Daytime temperatures at localities in the Valle de Neiba where these snakes were found are among the highest on the island. The average maximum temperature for Duvergé is $35.5^{\circ} \mathrm{C}$, but temperatures can reach $40.5^{\circ} \mathrm{C}$ in August. Similar conditions occur at La Descubierta, near the La Azufrada locality. Only two snakes were observed near midday (1315-1440 h), and in both instances they were pursuing prey in some of the most densely forested habitat in which the species had been encountered (at La Azufrada and La Placa). The individual (MNHNSD 23.1013) from east of Las Minas between Barahona and Azua was active at $1635 \mathrm{~h}$ when found crossing HW 44 and was killed by locals soon after.

While studying nesting activity in Rhinoceros Iguanas (Cyclura cornuta) at Fondo Paradí, Parque Nacional Jaragua 


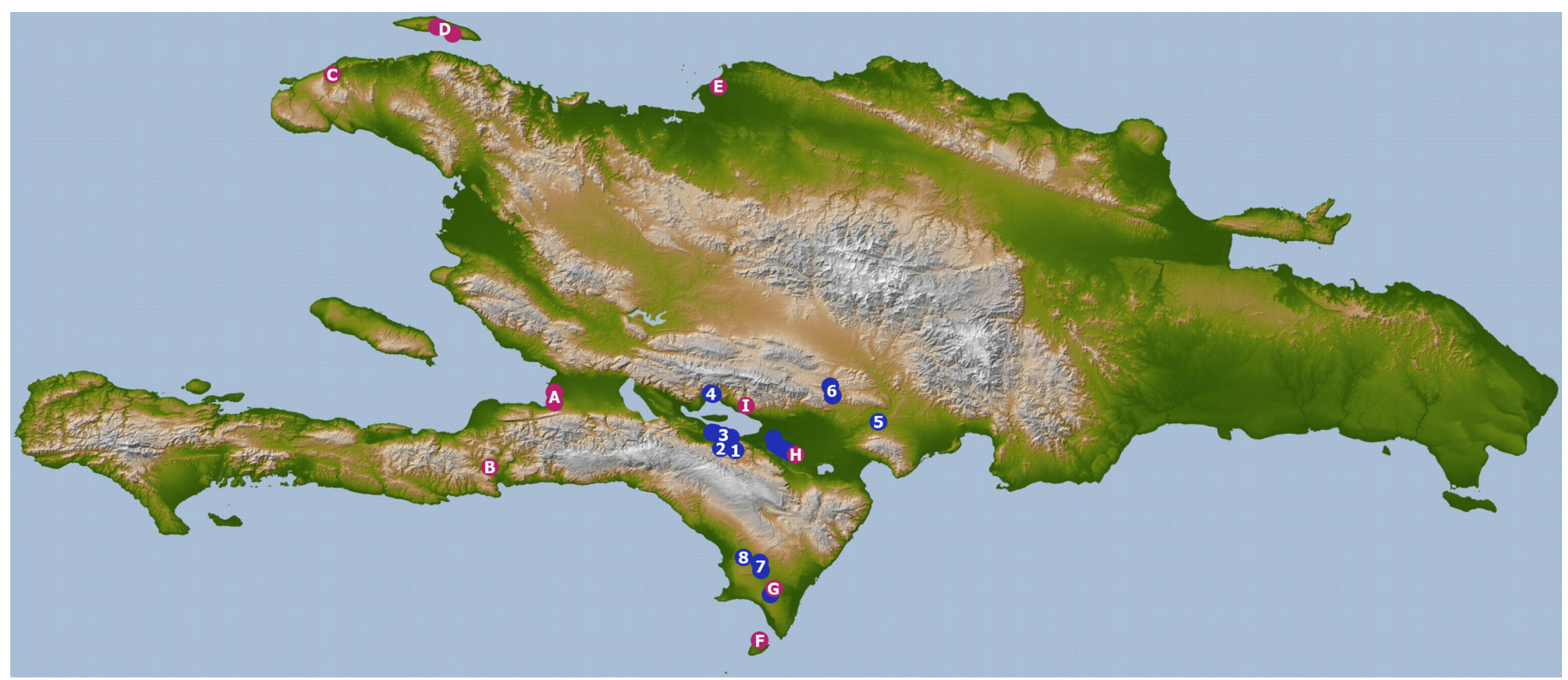

Fig. 3. Distribution of the Hispaniolan Brown Racer (Haitiophis anomalus). Purple dots labeled with letters represent historical records and blue dots marked with numbers are recent records. Note that the radius of each dot equals approximately $6 \mathrm{~km}$ on the map, so each locality, except those on offshore islands, is restricted to at least $5 \mathrm{~km}$ in dot-to-dot distance (airline). (A) Port-au-Prince, (B) N Jacmel, (C) Jean Rabel, (D) Île de la Tortue, (E) Monte Cristi, (F) Isla Beata, (G) Fondo Paradí, (H) HW 46-Mella-Colonia, and (I) Clavellinas; (1) El Rejanal, (2) La Placa-Florida, (3) Las Baitoas-Florida, (4) La Azufrada, (5) Las Minas (HW 44), (6) SE Cabeza de Toro, (7) Recta de Sansón, and (8) Loma del Burro. Basemap provided by John S. Parmerlee, Jr.

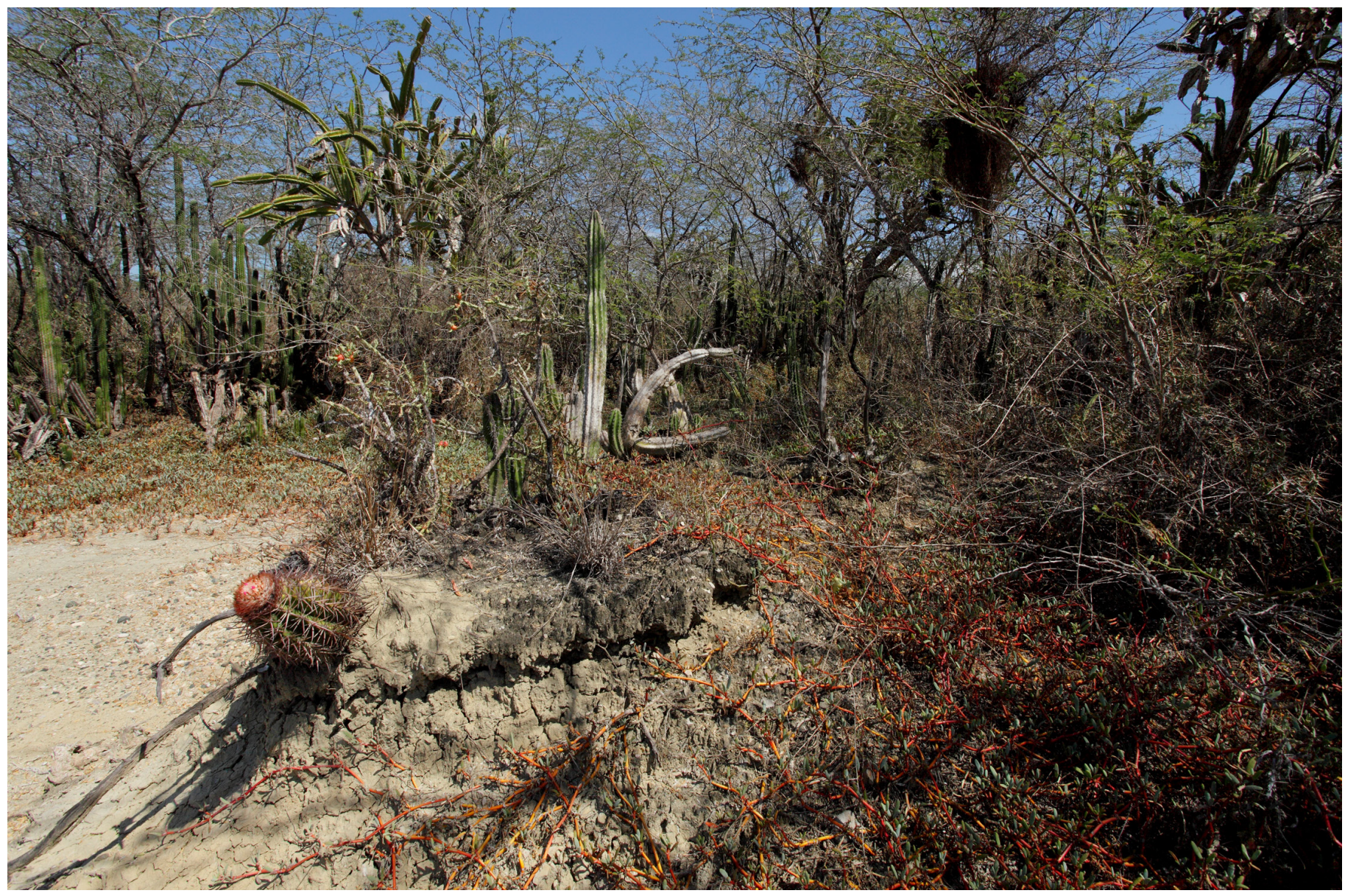

Fig. 4. Three roadkills have been found on HW 46 adjacent to apparently ideal habitat for the Hispaniolan Brown Racer (Haitiophis anomalus) in Parque Nacional La Gran Sabana in the Valle de Neiba, $3 \mathrm{~km}$ southeast of Mella (east of Duvergé) in Independencia Province. Photograph by Miguel A. Landestoy T. 


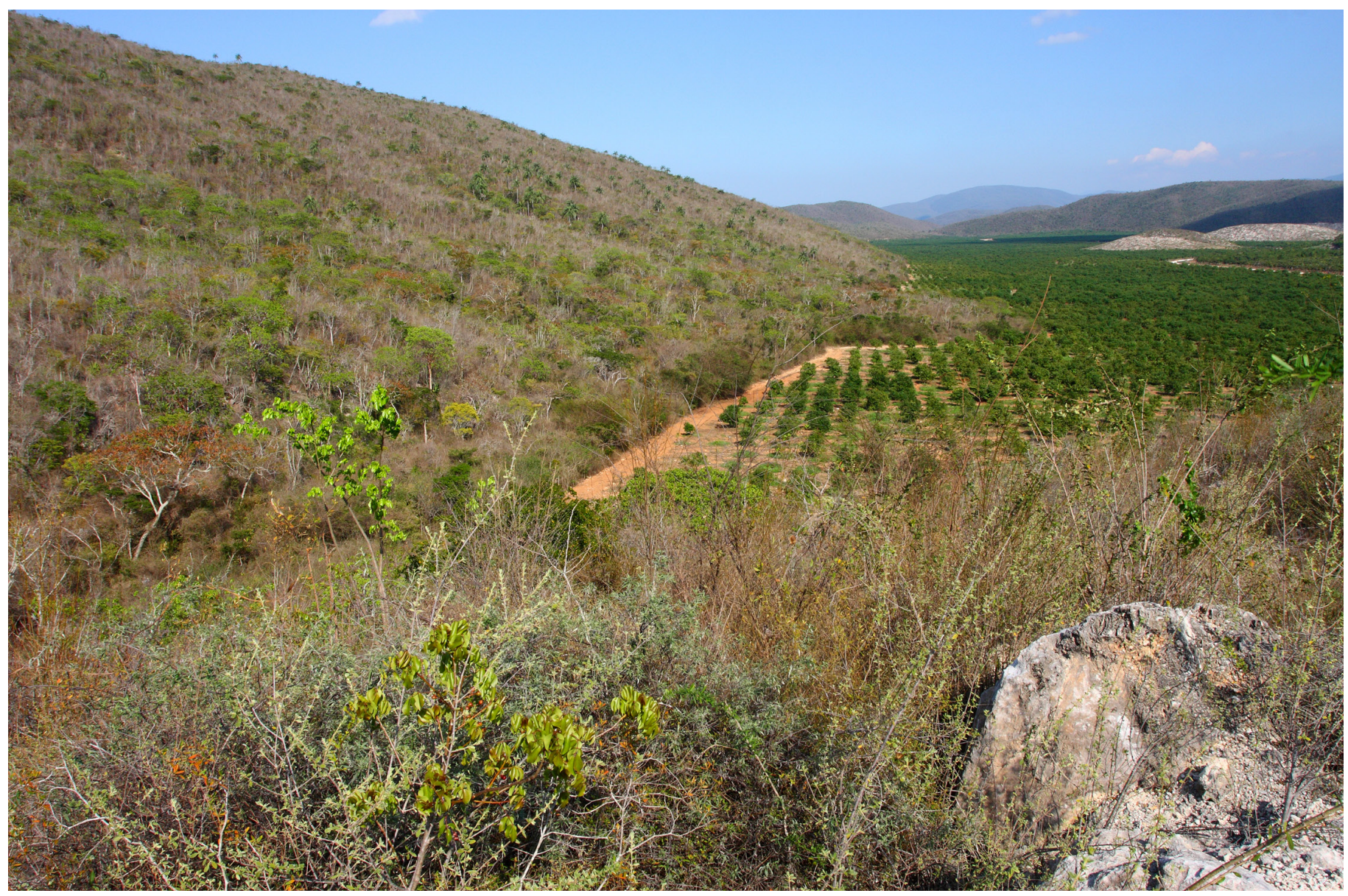

Fig. 5. In 2004, large portions of the natural habitat at El Rejanal, near the junction of the old road leading to Puerto Escondido from HW 46 were destroyed and the area was developed for avocado farming. Despite alterations to the landscape, two Hispaniolan Brown Racers (Haitiophis anomalus) were found on the dirt road that divides the farm. Photograph by Miguel A. Landestoy T. (April 2009).

on the Barahona Peninsula, ER employed camera traps during September and October in both 2010 and 2011 (also in June and July 2011) at an abandoned charcoal pit that had created a clearing in the forest. Fortuitously, the camera footage also captured apparent foraging by $H$. anomalus between 1030-1300 h on several occasions between 23 September 2010 and 10 July 2011 (Fig. 6). What could have been the same individual recorded on the camera traps was encountered $2 \mathrm{~m}$ above ground in dense foliage and vines on a bush $30 \mathrm{~m}$ from the pit at $0900 \mathrm{~h}$ on 18 October 2011; it was captured at $1000 \mathrm{~h}$ while still in same bush. This snake was $2.6 \mathrm{~m}$ total length, making it the second largest recorded specimen (after the snake reported by Thomas et al. 2007).

Encounters with $H$. anomalus are suggestive of seasonal differences in activity that coincide with weather patterns. Since our encounters with $H$. anomalus have been opportunistic, we acknowledge the possibility of a potential bias in regard to time spent in appropriate portions of the island. The senior author has traveled widely through the southern part of the Valle de Neiba (Cabral to La Florida) and to the northern slopes of the Sierra de Bahoruco, especially from January to early May. However, the area also has frequently been visited during the dry season, but only a single sighting of $H$. anomalus (10 January at La Azufrada) has occurred during the drier months of December, January, and February (Fig. 7). A similar situation occurs on the Barahona Peninsula where surveys were most frequent during September and October; the three roadkills found on the peninsula along the edge of and in the Parque Nacional Jaragua were in January (one) and September (two). Based on these preliminary data, $H$. anomalus appears to be more active during the rainy season, and we suggest that this could be correlated with its breeding season (that is, more conducive to prey availability and favorable conditions for egg development).

\section{Diet}

Based on 426 items recovered from preserved specimens of Hispaniolan dipsadids, frogs and lizards were the predominant prey, and lizards in the genus Anolis comprised more than half of all prey items (Henderson 1984). The only 
previously documented prey items for Haitiophis anomalus

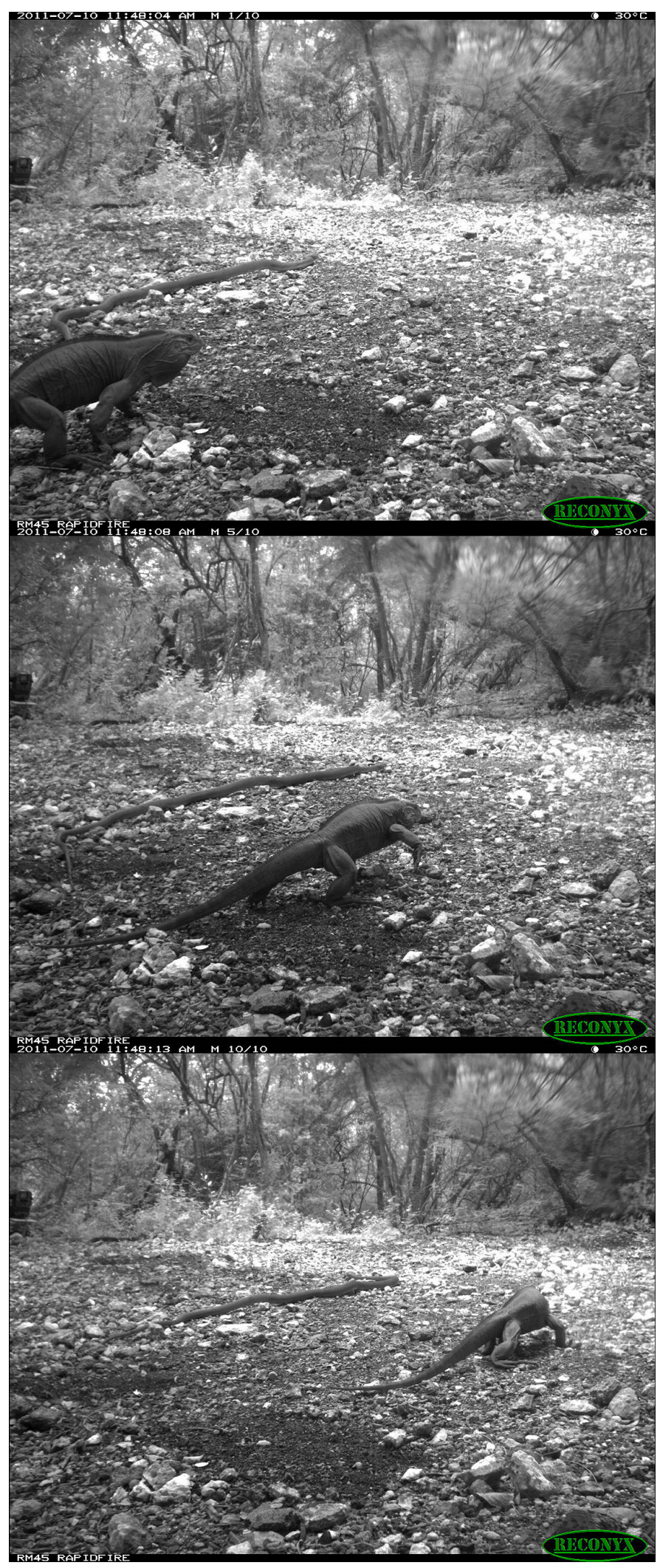

Fig. 6. Camera-trap images of a foraging Hispaniolan Brown Racer (Haitiophis anomalus) at midday at Fondo Paradí, Parque Nacional Jaragua on the Barahona Peninsula. Camera traps were employed in a study of nesting activity in Rhinoceros Iguanas (Cyclura cornuta) and fortuitously captured the snake as well. Photographs provided by Ernst Rupp. were an unidentified Anolis and an introduced rodent (Mus; Henderson and Sajdak 1996).

A freshly killed female with SVL of $1.75 \mathrm{~m}$ (MNHNSD 23.1013) was found on the afternoon of 10 October 2010 on HW 44 just east of the village of Las Minas (N18.47967 W71.03028) between Azua and Barahona Provinces. A prominent bulge in its stomach was a partially digested adult Smooth-billed Ani (Crotophaga ani, Cucculidae). The bird's remains consisted of black feathers, fairly intact tarsi $(35 \mathrm{~mm})$ with toes in zygodactyl arrangement, and the mandibles separated. When reassembled, the bill displayed the high keel typical of adults with a maximum length of 25.6 $\mathrm{mm}, 9.6 \mathrm{~mm}$ wide, and $21 \mathrm{~mm}$ deep. The digestion process was fairly advanced and whether the bird was killed by the snake or was encountered as carrion is unknown. A roadkill between La Azufrada and La Descubierta contained a small boa (Chilabothrus sp.; A. Schubert, pers. comm. 2013).

At $1440 \mathrm{~h}$, a $H$. anomalus was found chasing a rat (Rattus sp.) near the La Placa station of the Reserva Biológica Loma Charco Azul (D. Flores C., pers. comm. 2013). This snake was foraging under vegetation in shady conditions; it climbed into a tree to escape capture. At La Azufrada, a racer was in pursuit of a juvenile Rhinoceros Iguana (Cyclura cornuta) (D. Flores C., pers. comm. 2013). At Fondo Paradí (Parque Nacional Jaragua), a camera trap photographed $H$. anomalus foraging and inserting its head into the exit holes of an iguana (C. cornuta) burrow.

In captivity, an $H$. anomalus caught and held a mouse in its jaws with no application of coils. The mouse became immobile within about $40 \mathrm{sec}$ of capture and was bleeding profusely; it was subsequently swallowed. Half an hour later, the same snake attempted to capture another mouse, striking it and then coiling around it, but the prey managed to escape. It constricted for approximately 1-2 sec with three and onehalf coils. Other prey offered and eaten was a medium-sized Hispaniolan Giant Anole (Anolis baleatus). Rejected prey included baby chicks and lizards, a Hispaniolan Keeled Galliwasp (Celestus stenurus) and a Hispaniolan Masked Curlytail (Leiocephalus personatus).

Based on these meager data, $H$. anomalus likely is a trophic generalist as prey data collected in the field include lizards (Anolis), snakes (Chilabothrus sp.), birds (Crotophaga), and mammals (Mus).

\section{Reproduction}

The only information available on reproduction was that of Cochran (1941), who reported a gravid female that contained 22 ovarian eggs on 8 May. A female roadkill photographed by K. Wollenberg on 16 October 2009 contained eggs that were crushed and could not be counted. We videotaped obvious courtship behavior in May 2009 by a captive male and a recently (2 days) captured female (MNHNSD 23.1053) that shared an enclosure for several weeks. The male aligned itself 


\section{Monthly Rainfall 1990-2004}

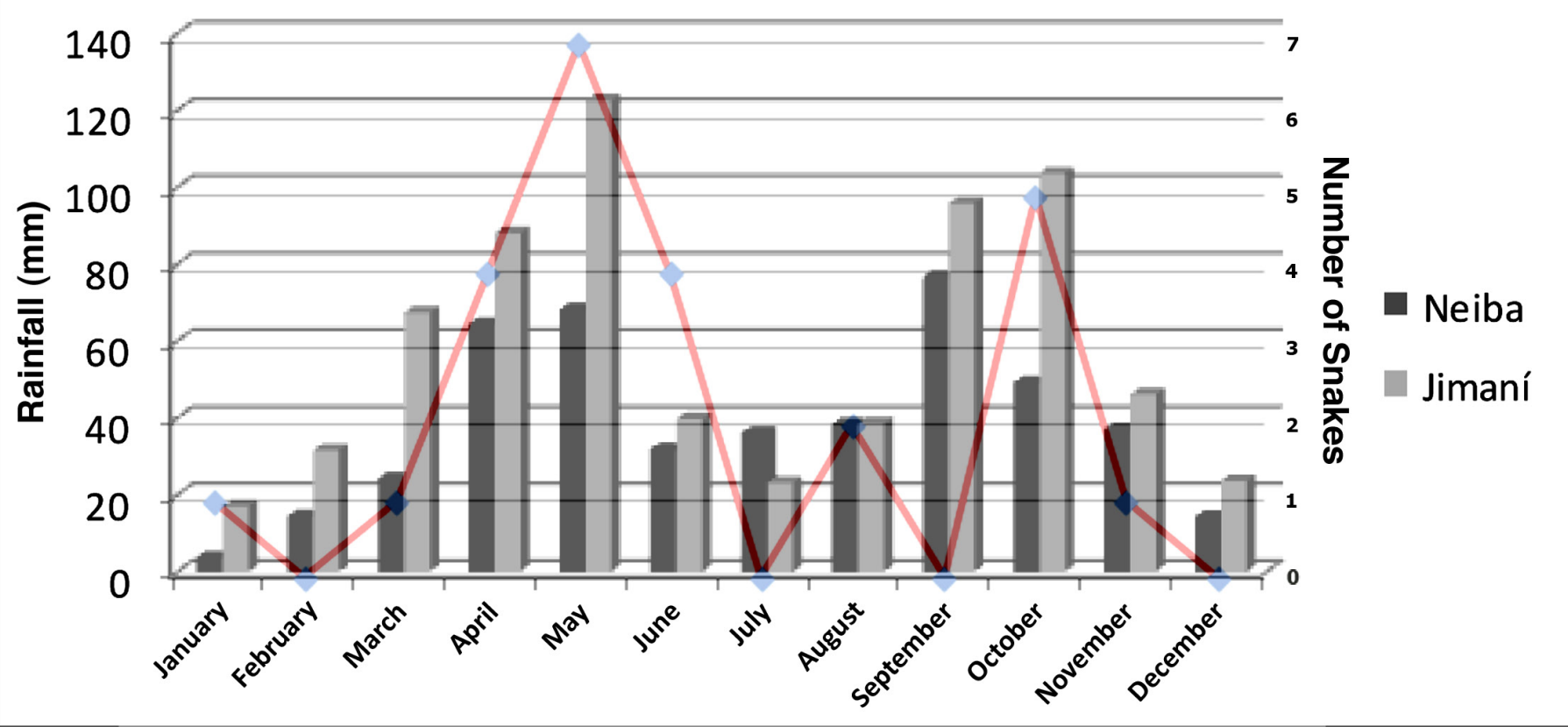

Fig. 7. Rainfall and numbers of Hispaniolan Brown Racers (Haitiophis anomalus) found in the Valle de Neiba and surrounding uplands. Rainfall data are from both eastern (Neiba, dark shading) and western (Jimaní, pale shading) extremes of Lago Enriquillo. The line indicates the number of snakes encountered during each month. Modified from Schubert (2012).

atop the female, often head-bobbing. At times he would move slightly lateral to the female. The female seemed disinterested and rejected the male's close approach by whipping her tail or by abruptly moving part of her midbody to push him away. This behavior was observed repeatedly for almost a week. Although the male was interested, we could not determine if the female's lack of interest was due to stress induced by captivity or if she had already been fertilized. She was examined after preservation and found not to be gravid.

The likelihood of a defined breeding season correlated with rainfall is based on the two gravid females, the increased frequency of individuals found in May and October, and the behavior observed in captivity.

\section{Defensive Behavior}

Several defensive behaviors have been observed. Ducoudray (1981) reported hooding by a large Haitiophis anomalus of unknown sex, and we have witnessed similar behavior (Fig. 8). Hooding has been observed in other species formerly assigned to Alsophis, most notably Borikenophis portoricensis (Fig. 27 in Henderson and Powell 2009) and Cubophis cantherigerus, as well as the Hispaniolan endemic Antillophis (Hypsirhynchus) parvifrons. Like many snakes, if cornered or approached too closely, H. anomalus will strike. Captured males everted their hemipenes. Rapid rotation of the body was employed when handled; similar behavior is not unusual in a variety of snake taxa. Some individuals whipped their tails, possibly as a means of distracting attention away from the head.

\section{Conservation Concerns}

Lago Enriquillo doubled its surface between 2004 and 2011, from 165 to $333 \mathrm{~km}^{2}$ (Schubert 2012). This resulted in the flooding of agricultural areas, cattle pastures, and forested areas that in turn forced the area's communities to move up in elevation away from the lakeshores. Both the direct impact of the flooding and that of people modifying the surrounding landscape (Fig. 9) have likely affected the Haitiophis anomalus population in the area. This could be measured by the incidence of dead snakes we have found in recent years in the Valle de Neiba, most of them roadkills. Snakes presumably have been killed by humans in some recently plowed areas, especially at one site near Mella (N18.358877, W71.427195), where we found the greatest concentration of individuals $(\mathrm{n}=5)$ in a localized area (i.e., all snakes were within about $350 \mathrm{~m}$ ). Recently, a massive land development project undertaken by the Instituto Agrario Dominicano has 
cleared extensive portions of land that included suitable habitat for $H$. anomalus and specific sites where the species has been found. Also included in the development is a protected area, the Reserva Biológica Loma Charco Azul, where ten $H$.
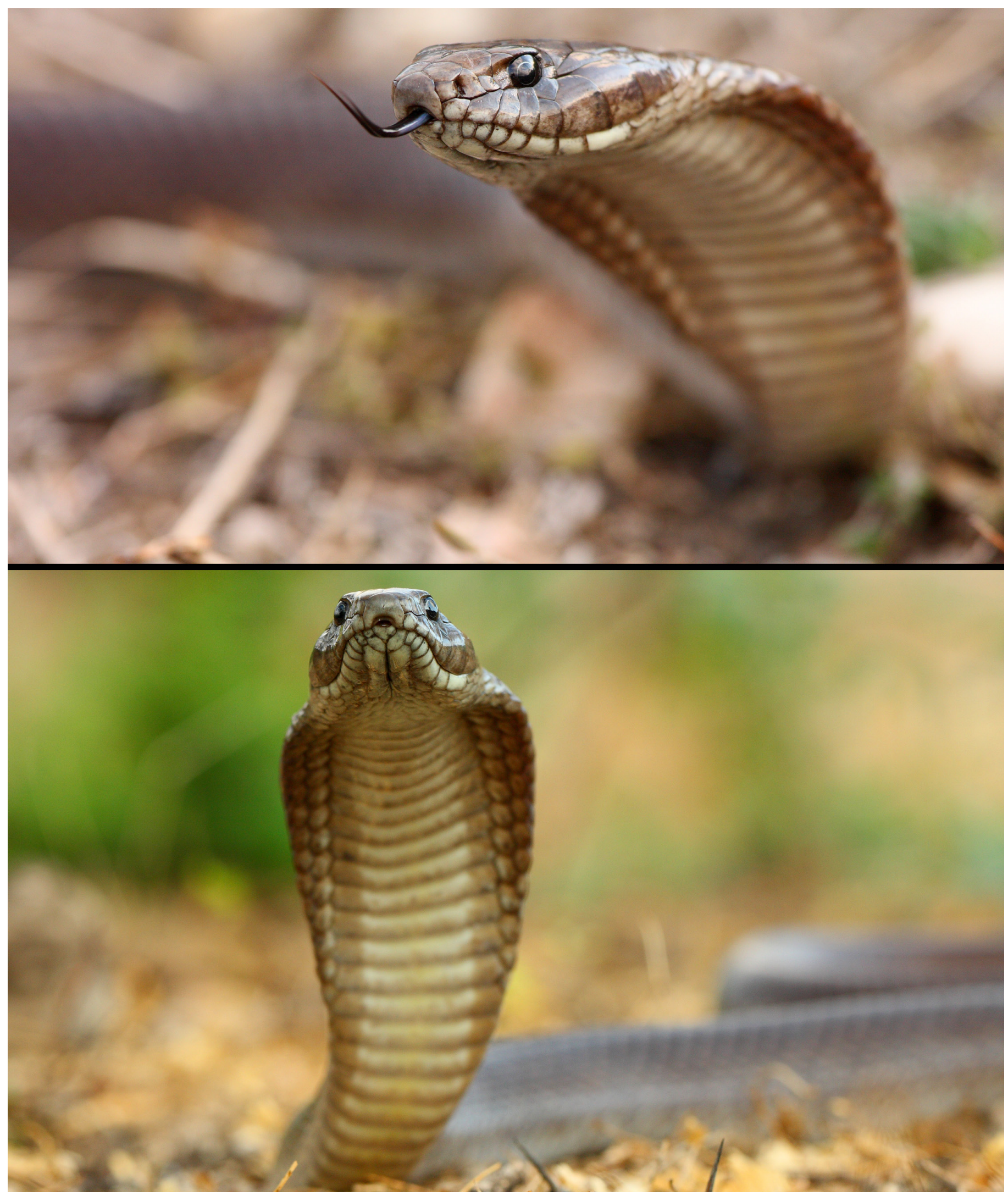

Fig. 8. Hooding Hispaniolan Brown Racer (Haitiophis anomalus) captured and later released at El Rejanal in the Puerto Escondido Valley. Photographs by Miguel A. Landestoy T. 


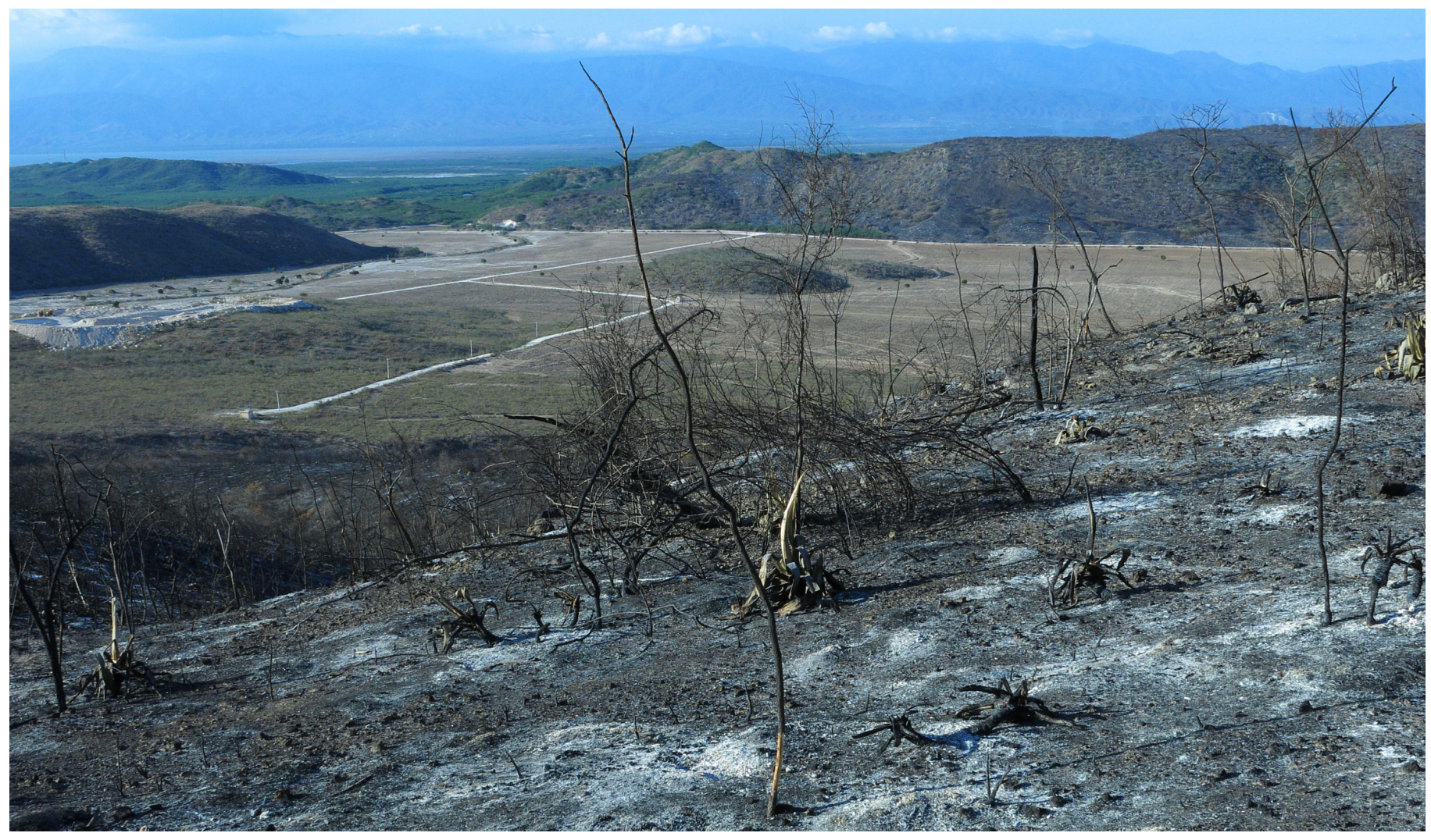

Fig. 9. El Espartillar east of Duvergé. View to the eastern end of Lago Enriquillo where the hillsides were burned after a fire presumably went out of control in an area cleared for an agricultural project. Hispaniolan Brown Racers (Haitiophis anomalus) have been found near here and habitat had been suitable. Photograph by Miguel A. Landestoy T.

anomalus were found at various localities. Wood harvesting for charcoal production has been intense in recent decades throughout the region (Rupp et al. 2007) and has substantially altered the natural vegetation. Goats run free almost everywhere in the hills and lowlands and certainly contribute to habitat degradation. Similar threats occur east of Duvergé at Parque Nacional La Gran Sabana.

We have observed mongooses and feral cats in areas inhabited by Haitiophis anomalus. The camera traps at Fondo Paradí recorded an encounter between a racer and a feral cat (Fig. 10); the snake was $2.6 \mathrm{~m}$ total length and the cat ran away. Surprisingly, mongooses and cats occur at the driest and one of the lowest areas of the snake's range along the Valle de Neiba (N18.411087, W71.637125). Red-tailed Hawks (Buteo jamaicensis) have been observed hunting at $H$. anomalus sites (near La Florida, near Las Salinas west of Cabral, and in the nearby foothills of the Sierra de Bahoruco), and they could represent a natural predator. However, we have no documented evidence of predation on $H$. anomalus by any species other than humans. Educational efforts directed toward local communities must address the benefits of this species in an agricultural setting (rodent control) and reinforce the reality that it poses no danger to humans.

Despite extreme conditions, the Valle de Neiba and the Parque Nacional Jaragua have proven to be suitable and

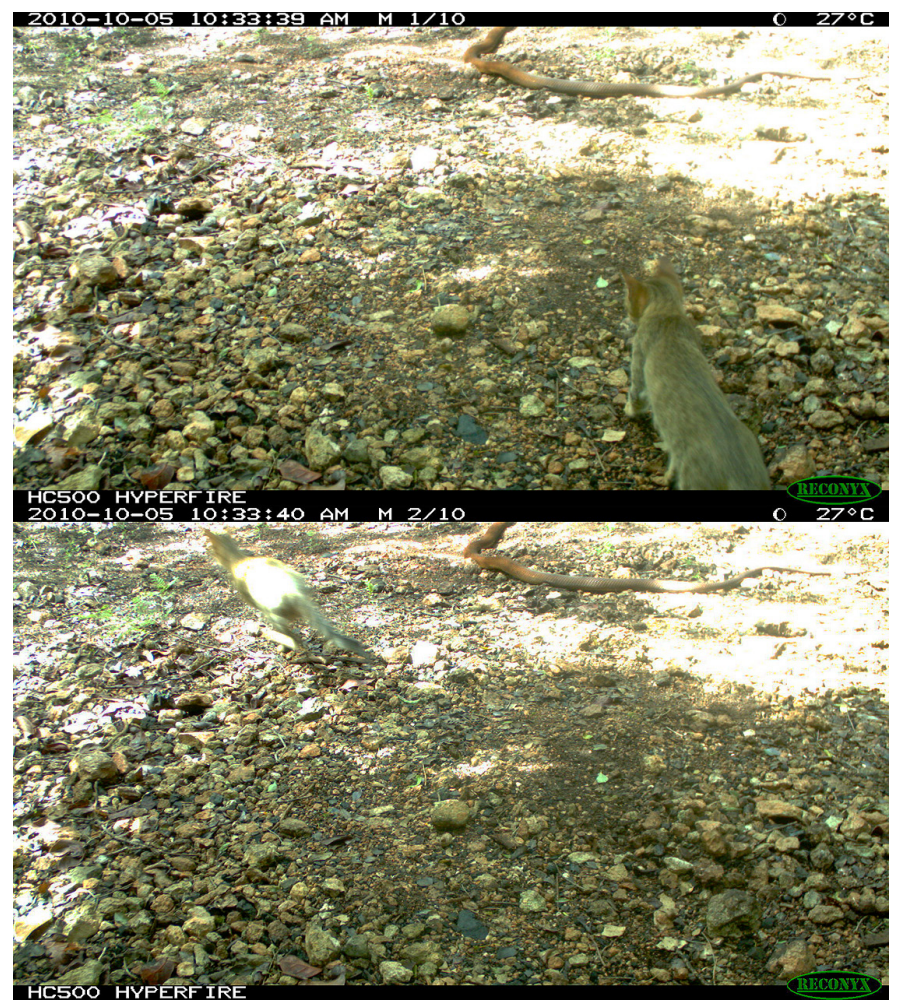

Fig. 10. Camera-trap images of an encounter between a feral cat and a foraging Hispaniolan Brown Racer (Haitiophis anomalus) at Fondo Paradí, Parque Nacional Jaragua on the Barahona Peninsula. Photographs provided by Ernst Rupp. 
reliable areas in which to conduct research on this species. Radio telemetry would help to understand its activity patterns and habitat use. These data could then be used to generate a model for conserving these charismatic snakes in other areas where the species occurs.

\section{Acknowledgments}

We thank Daniel Scantlebury, Yoel Hernández, Gerson Féliz, Jairo Arache Matos, Edison Melo, Michael Hano, and Jürgen Hoppe for their invaluable help in the field, and Elvi de los Santos for assisting with laboratory work. Darío Flores Chávez, Andreas Schubert, Katharina Wollenberg, and Sixto Incháustegui generously contributed observations and field experience. The Museo de Historia Natural de Santo Domingo encouraged our research and the publication of our data. Robert Powell, Angela Guerrero, and Blair Hedges provided helpful comments on earlier versions of this note. Permission for the Project, "Biogeografía de los Reptiles y Anfibios de la Hispaniola" (No. 24327), was granted by the Ministerio de Medio Ambiente y Recursos Naturales (MIMARENA), and previous work and authorizations were facilitated by Dr. Jaime David Fernández M. and Eleuterio Martínez.

\section{Literature Cited}

Cochran, D.M. 1941. The herpetology of Hispaniola. Bulletin of the U.S. National Museum (177):vii + 398 pp.

Ducoudray. F.S. 1981. La Isla de la Serpiente, pp. 137-145. In: Investigaciones en las Islas Beata y Alto Velo. Serie Investigaciones Antropológicas 18. Museo del Hombre Dominicano y Marina de Guerra, Santo Domingo.
Grupo Jaragua. 2008. Refugio de Vida Silvestre La Placa: Propuesta. Informe no publicado. Grupo Jaragua, Santo Domingo.

Hedges, S.B., A. Couloux, and N. Vidal. 2009. Molecular phylogeny, classification, and biogeography of West Indian racer snakes of the tribe Alsophiini (Squamata, Dipsadidae, Xenodontinae). Zootaxa (2067):1-28.

Hedges, S.B. and C.E. Conn. 2012. A new skink fauna from Caribbean islands (Squamata, Mabuyidae, Mabuyinae). Zootaxa (3288):1-244.

Henderson, R.W. 1984. The diets of Hispaniolan colubrid snakes I. Introduction and prey genera. Oecologia 6:234-239.

Henderson, R.W. and R.A. Sajdak. 1996. Diets of West Indian racers (Colubridae: Alsophis): Composition and biogeographic implications, pp. 317-326. In: R. Powell and R.W. Henderson (eds.), Contributions to West Indian Herpetology: A Tribute to Albert Schwartz. Contributions to Herpetology, volume 12, Society for the Study of Amphibians and Reptiles, Ithaca, New York.

Henderson, R.W. and R. Powell. 2009. Natural History of West Indian Reptiles and Amphibians. University of Florida Press, Gainesville.

Martínez B., J.R. 2012. Sierra de Bahoruco Occidental, República Dominicana: Estudio Biogeomorfológico y Estado de Conservación de su Parque Nacional. Tesis Doctoral, Universidad de Sevilla, Spain.

Powell, R. and R.W. Henderson. 1998. Alsophis anomalus. Catalogue of American Amphibians and Reptiles (659):1-2.

Rodríguez, P.G. 2006. Extremely rare snake found at Jaragua National Park. The Palm Chatter (Newsletter of the Sociedad Ornitológica de la Hispaniola) 1(2):3.

Rupp, E., S.J. Incháustegui, and Y. Arias. 2007. Preliminary report on the distribution and status of Cyclura ricordii along the southern shore of Lago Enriquillo. Iguana 14:3-7.

Schubert, A. 2012. Lagos Enriquillo y Azuéi: Donde la naturaleza siempre tiene una sorpresa. Editorial Academica Española.

Schwartz, A. and R.W. Henderson. 1991. Amphibians and Reptiles of the West Indies: Descriptions, Distributions, and Natural History. University Press of Florida. Gainesville.

Thomas, R., R.W. Henderson, R. Powell, and P.G. Rodríguez. 2007. Alsophis anomalus (Hispaniolan Brown Racer). Maximum size. Herpetological Review 38:338-339. 